J. Lake Sci. (湖泊科学), 2015, 27 (6): 1035-1041

DOI 10. 18307/2015. 0607

(C) 2015 by Journal of Lake Sciences

\title{
扎龙国家级自然保护区硅藻植物特征及其环境指示作用"
}

易映䑣, 李 慧, 刘 妍, 范亚文 ${ }^{* *}$

(哈尔滨师范大学植物学省级重点实验室, 哈尔滨 150025)

摘 要: 2011 年春、夏、秋季对扎龙国家级自然保护区内的硅藻群落结构进行研究. 通过鉴定, 共发现硅藻门植物 112 个 分类单位,包括 96 种 16 变种, 隶属于 2 纲 6 目 9 科 32 属. 通过对硅藻植物的种类组成、聚类分析等方法, 对扎龙国家级自 然保护区内的硅藻植物分布情况进行初步研究, 结果表明, 扎龙国家级自然保护区内硅藻植物种类较为丰富, 保护区内 水体普遍为受轻污染或中度污染状态, 个别水域存在富营养化情况, 春、夏、秋季节中, 秋季的富营养情况较为严重. 结合 水体的理化指标, 通过对扎龙国家级自然保护区水体中硅藻的优势种、指示种的分析, 发现该水域喜碱性、半咸水种类及 中污带的种类较多, 说明保护区水体受到轻微的污染, 个别水域出现富营养状态. 扎龙国家级自然保护区水体呈中 - 弱 碱性、微盐,表明该区域受到了土地盐碱化的影响.

关键词: 扎龙国家级自然保护区; 硅藻植物群落; 聚类分析

\section{Diatom composition and its application in water quality assessment in the Zhalong Nation- al Nature Reserve, China}

\author{
YI Yingtong, LI Hui, LIU Yan \& FAN Yawen \\ (College of Life Science and Technology, Harbin Normal University, Harbin 150025, P. R. China)
}

\begin{abstract}
As the largest wetland nature reserve area for cranes and other large water birds in China, Zhalong National Nature Reserve plays an important role in maintaining regional ecological security. In 2011, composition structure of diatom communities were investigated during spring, summer and autumn. The biodiversity of diatom in this area are relatively high and totally 112 taxa (including 96 species, 16 varieties) were identified, belonging to 2 classes, 6 orders, 9 families and 32 genera. The diatom communities were analyzed by principal component analysis and cluster analysis was employed to analysis the relationship between diatom and environmental parameters. It showed that conductivity, total phosphorus and total nitrogen have great influence on the diatom distribution. Through the analysis, species preferring to alkaline and semi-alkaline habitat were identified, such as Navicula radiosa Kütz. , Epithemia adnata, Fragilaria ulna var. acus (Kütz. ) Lange-Bertalot. Due to the effect of land salinization, the water was affected by the alkaline and sort of salty weakly. Combined with the physical and chemical indicators of the water, we conclude that the water quality in Zhalong National Nature Reserve have been polluted slightly.
\end{abstract}

Keywords: Zhalong National Nature Reserve; diatom communities; cluster analysis

浮游植物是水生态系统的初级生产者, 是整个水生态系统物质循环和能量流动的基础 ${ }^{[1]} .1970 \mathrm{~s}$ 以来, 许多江、河、湖泊、水库等生态系统功能一直在下降 ${ }^{[2]}$. 作为浮游植物中的主要成员一一硅藻植物在自然界 中分布极广, 它在河流、湖泊的多样性研究中始终扮演着重要的角色, 其群落结构与生存环境密切相关, 既 受环境因子的影响又能灵敏地反映环境的变化特征, 在变化的水环境中, 硅藻提供了不同的指示植物, 因 此,利用硅藻的指示作用监测水质的污染情况进而评价流动水体的生物监测方法已得到广泛应用 ${ }^{[3]} .2000$ 年欧盟水框架指导委员会 (Water Framework Directive of the European Union) 已将硅藻确定为当前水环境监

* 国家自然科学基金项目(31070183、31270250)、黑龙江省教育厅重点项目(12521 z011)、黑龙江省高校科技创新团 队研究计划和哈尔滨师范大学科技创新团队研究计划 (KJTD-2011-2) 联合资助. 2014-12-18 收稿;2015-04-16 收修改稿. 易映形(1988 ), 女, 硕士研究生; E-mail:408420776@ qq. com.

** 通信作者;E-mail:fanyaw@163.com. 
测及整治决策中可以用来评价营养水平的重要生物指标, 截止 2007 年, 该监测框架几乎兼容了所有的欧盟 成员国 ${ }^{[4-5]}$. 相对于国外的大量研究 ${ }^{[6-8]}$, 近几年, 我国一些学者 ${ }^{[9-11]}$ 已开始利用硅藻植物对水域变化进行了 相应的研究, 并利用淡水环境中硅藻植物群落结构开展环境监测工作.

扎龙国家级自然保护区 $\left(46^{\circ} 52^{\prime} \sim 47^{\circ} 32^{\prime} \mathrm{N}, 123^{\circ} 47^{\prime} \sim 124^{\circ} 37^{\prime} \mathrm{E}\right)$, 位于黑龙江省西部, 松嫩平原乌裕尔 河下游, 是我国最大的以鹤类等大型水禽为主体的珍稀鸟类和湿地生态类型的国家级自然保护区, 属于典 型的河滨湿地, 平均海拔 $144 \mathrm{~m}$, 其中湿地 (湖泊、沼泽) 面积 $1240 \mathrm{~km}^{2}$. 这里属北温带大陆性季风气候, 年平 均气温 $2.0 \sim 4.2^{\circ} \mathrm{C}$, 多年平均降雨量 $416 \mathrm{~mm}$, 降水多集中在 7-9 月份. 湿地内分布众多泡沼, 蒸发强烈, 土 地盐碱化较普遍. 1992 年扎龙国家级自然保护区被列人国际重要湿地名录 ${ }^{[12-14]}$.

2011 年春、夏、秋季对扎龙国家级自然保护区内的硅藻群落结构进行研究, 对其种类组成、数量分布及 其与环境因子的关系进行分析, 并利用硅藻植物生态指标评价其水质营养状态, 为扎龙国家级自然保护区 生态环境保护和维持保护区的可持续发展提供基础资料.

\section{1 材料与方法}

\section{1 采样点的布设}

扎龙国家级自然保护区分布着成片或断续的芦苇沼泽、苔草沼泽及湖泡, 也是鹤类等珍稀水禽的活动 领域和栖息繁殖地, 区内村屯较多,有铁路、公路干线和大型水利工程. 在扎龙国家级自然保护区的实验区

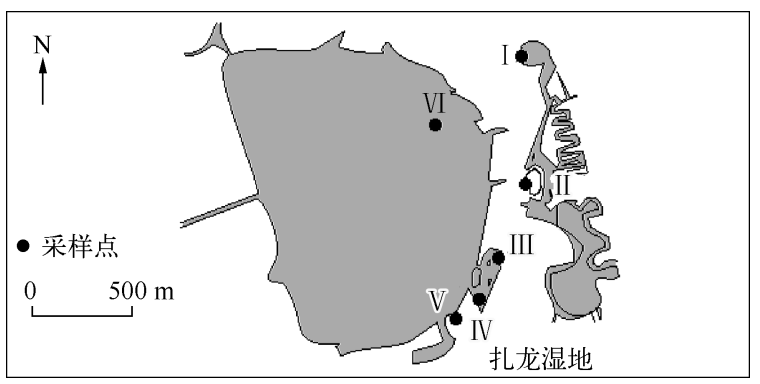

图 1 扎龙国家级自然保护区采样点位置

Fig. 1 The distribution of sampling sites in the Zhalong National Nature Reserve 中,共布设 6 个采样点 (图 1). 采样点 I 位于保 护区的最东北部, 是保护区具有代表性大片 开放的芦苇类型水域, 此处游客较多, 受人 为影响较大; 采样点 II 位于丹顶鹤养殖区附 近的小型水泡, 水域面积较小, 丹顶鹤等大 型水禽常在此处活动; 采样点 III 、 IV、V 均位 于旅游景点处的水域, 生态类型分别为较小 型湖泊、水流速度较缓的区域及芦苇沼泽; 采样点 VI位于扎龙湖中, 水域面积较大, 受 上游农田和人为活动的影响较大, 这 6 个采 样点代表扎龙国家级自然保护区生态环境 的基本特征.

\section{2 样品的采集}

2011 年春季 (5 月)、夏季 (7 月) 和秋季 (10 月) 分别按照常规方法 ${ }^{[15-16]}$ 进行硅藻植物水质样品采集, 采 集后的样品用 $4 \%(\mathrm{~V} / \mathrm{V})$ 甲醛固定保存.

\section{3 理化指标的测定}

现场测定水环境的温度 (WT)、 $\mathrm{pH}$ 、电导率 ( Cond) 和海拔 $(\mathrm{H})$. 在实验室中, 水样需在 $24 \mathrm{~h}$ 之内测定生 物需氧量 $\left(\mathrm{BOD}_{5}\right)$ 、化学需氧量 $\left(\mathrm{COD}_{\mathrm{Cr}}\right)$ 、高锰酸盐指数 $\left(\mathrm{COD}_{\mathrm{Mn}}\right)$ 、总氮 $(\mathrm{TN})$ 、总磷 $(\mathrm{TP})$ 、溶解氧 $(\mathrm{DO})$ 浓度 等理化指标. 其中, $\mathrm{BOD}_{5}$ 采用 BOD-Sytem OxDirect ( Italy) 测定; $\mathrm{COD}_{\mathrm{Mn}}$ 采用 COD-Reaktor ET 108 测定; TN、TP 浓度采用多离子微电脑测量仪测定; DO 浓度采用碘量法测定.

\section{4 样品的处理、鉴定和计数}

在实验室中对定性的样品进行酸处理以去除泥沙和有机质, 之后用蒸馏水清洗样品, 3000 转/ $\mathrm{min}$ 离心 6 次, 每次 $5 \mathrm{~min}$, 最后保存在 $75 \%$ 酒精中, 并用 Naphrax 胶制作成永久封片. 每个采样点封片在 $10 \times 100$ 倍 的光镜下随机计数至少 500 个硅藻壳面, 鉴定到种 ${ }^{[17-20]}$. 运用 Primer 5.0 和 C2 软件对硅藻植物群落聚类、丰 度进行作图和分析.

\section{2 结果与分析}

\section{1 扎龙国家级自然保护区硅藻植物种类组成}

通过鉴定, 扎龙国家级自然保护区内共发现硅藻门植物 112 个分类单位,包括 96 种 16 变种,隶属于 2 
纲 6 目 9 科 32 属. 优势种为纤细等片藻、弯棒杆藻、隐头舟形藻、尖布纹藻、明晰双肋藻、窄异极藻、波罗的海 胸膈藻、海生胸膈藻双头变种 (表 1 ).

扎龙国家级自然保护区不同季节的硅藻植物种类有所差异: 夏季出现的种类最多, 为 57 种; 其次是秋 季, 为 53 种; 春季出现的种类最少, 为 49 种. 采样点 $\mathrm{IV} 、 \mathrm{~V}$ 的物种较为丰富, 种类数分别为 $43 、 59$ 种.

表 1 扎龙国家级自然保护区主要硅藻种类组成及分布

Tab. 1 Constitute and distribution of dominated diatom species in the Zhalong National Nature Reserve

\begin{tabular}{|c|c|c|c|c|c|c|c|c|c|c|c|c|c|c|c|c|c|c|c|}
\hline \multirow{2}{*}{ 种类 } & \multirow{2}{*}{$\begin{array}{l}\text { 种名 } \\
\text { 缩写 }\end{array}$} & \multicolumn{6}{|c|}{ 春季 } & \multicolumn{6}{|c|}{ 夏季 } & \multicolumn{6}{|c|}{ 秋季 } \\
\hline & & I & II & III & $\mathrm{IV}$ & $\mathrm{V}$ & VI & $\mathrm{I}$ & II & III & $\mathrm{IV}$ & V & $\mathrm{VI}$ & $\mathrm{I}$ & II & III & IV & $\mathrm{V}$ & VI \\
\hline 简单曲壳藻( Achnanthes simplex) & Ac-si & & & & & ++ & & & & & & & & + & & & + & + & \\
\hline 极细微曲壳藻 (Achnanthes minutissima) & Ac-mi & & & & & & & & & & & & & ++ & + & + & ++ & ++ & \\
\hline 明晰双胁藻 ( Amphipleur pellucida) & Am-pe & + & ++ & ++ & +++ & ++ & + & & +++ & + & ++ & + & + & + & + & ++ & ++ & + & + \\
\hline 短角美壁藻( Caloneis silicula) & Ca-si & + & & & & & + & + & & & & ++ & & & + & + & & & + \\
\hline 扁圆卵形藻( Cocconeis placentula) & Co-pl & & & & & & & & + & + & & + & ++ & & & & & & \\
\hline $\begin{array}{l}\text { 扁圆卵形藻线条变种 (Cocconeis } \\
\text { placentula var. lineata) }\end{array}$ & Co-pl-li & & & & & & & & & + & & + & & ++ & & ++ & ++ & ++ & \\
\hline 梅尼小环藻( Cyclotella meneghiniana) & Cy-me & + & + & + & + & ++ & & + & ++ & & + & + & & + & & + & + & & \\
\hline 箱形桥弯藻( Cymbella cistula) & Cy-ci & & + & & + & & & + & & + & ++ & & & + & & + & & + & \\
\hline 切断形桥弯藻( Cymbella excisiformis) & Cy-ex & & & & & + & & + & & & & + & ++ & & & & & + & + \\
\hline 细角桥弯藻( Cymbella neoleptoceros) & Cy-ne & & & & & & ++ & & + & & & & ++ & & & & & ++ & ++ \\
\hline 纤细等片藻( Diatoma tenuis) & Di-te & +++ & +++ & + & + & + & + & & & & + & + & & & & & & & + \\
\hline 侧生窗纹藻( Epithemia adnata) & Ep-ad & + & & ++ & + & + & & + & + & + & ++ & + & + & + & & + & + & + & \\
\hline 鼠形窗纹藻 (Epithemia sorex) & Ep-so & & & & + & + & + & + & & + & ++ & ++ & ++ & + & + & + & + & + & + \\
\hline 细弱脆杆藻 (Fragilaria tenera) & Fr-te & ++ & & & + & + & & + & + & & + & & & & & & & & \\
\hline 窄异极藻( Gomphonema angustatum) & Go-an & & + & + & + & & + & & & + & + & + & + & & +++ & & & & ++ \\
\hline 尖布纹藻( Gyrosigma acuminatum) & Gy-ac & & +++ & & & + & & & & & & & & + & & + & & + & \\
\hline 波罗的海胸膈藻 (Mastogloia baltica) & Ma-ba & & & & + & & ++ & & & +++ & ++ & + & & & & & & & \\
\hline 施密斯胸膈藻 (Mastogloia smithii) & Ma-sm & & & & & + & & & & ++ & & + & & & & & & & \\
\hline $\begin{array}{l}\text { 海生胸膈藻双头变种 (Mastogloia } \\
\text { smithii var. amphicephala) }\end{array}$ & Ma-sm-am & & + & ++ & + & + & & + & & +++ & ++ & + & ++ & + & ++ & ++ & + & + & + \\
\hline 意大利直链藻 (Melosira italica) & Me-it & & + & + & ++ & + & + & & & + & + & + & & + & & + & & + & \\
\hline 微小舟形藻( Navicula atomus) & Na-at & & ++ & + & + & ++ & & + & & + & + & + & ++ & ++ & ++ & ++ & ++ & ++ & + \\
\hline 辐头舟形藻 ( Navicula capitatoradiata) & $\mathrm{Na-ca}$ & & ++ & & & & & & & & & + & & + & + & & & + & \\
\hline 隐头舟形藻( Navicula cryptocephala) & $\mathrm{Na}-\mathrm{cr}$ & + & ++ & + & +++ & ++ & +++ & ++ & & ++ & +++ & ++ & ++ & ++ & ++ & +++ & +++ & ++ & +++ \\
\hline 隐柔舟形藻 (Navicula cryptotenella) & Na-crlla & & & & & & & & ++ & & & & & + & + & & + & + & \\
\hline 扁圆舟形藻( Navicula placentula) & Na-pl & & & & & & & & & & & ++ & & & & & & + & \\
\hline 放射舟形藻( Navicula radiosiola) & Na-ra & & ++ & ++ & ++ & ++ & & ++ & ++ & + & ++ & + & ++ & + & & ++ & ++ & ++ & + \\
\hline 针状菱形藻( Nitzschia acicularis) & Ni-ac & ++ & & + & + & ++ & & & & & + & & & + & & + & + & + & \\
\hline 两栖菱形藻( Nitzschia amphibia) & Ni-am & & & & & & & ++ & & + & & & & & & + & & & \\
\hline 小头端菱形藻 ( Nitzschia capitellata) & $\mathrm{Ni}-\mathrm{ca}$ & & & & & & & & & & + & & & & + & & + & + & \\
\hline 新月菱形藻( Nitzschia gracilis) & $\mathrm{Ni}$-gr & + & & ++ & & + & & & + & & & & & & + & + & + & & \\
\hline 谷皮菱形藻( Nitzschia palea) & Ni-pa & ++ & ++ & ++ & & + & & & +++ & ++ & & ++ & & ++ & ++ & + & ++ & & \\
\hline 管栖菱形藻( Nitzschia tubicola) & Ni-tu & & & ++ & & + & & & & & & & & + & + & + & & & \\
\hline 弯棒杆藻 (Rhopalodia gibba) & Rh-gi & & + & +++ & ++ & ++ & ++ & +++ & ++ & ++ & ++ & ++ & ++ & + & ++ & ++ & + & ++ & ++ \\
\hline 线毛平板藻 (Tabellaria flocculosa) & Ta-fl & & + & + & + & + & ++ & + & & + & ++ & & & & & & + & + & + \\
\hline
\end{tabular}

+ 表示存在; ++ 表示常见种; +++ 表示优势种.

\section{2 扎龙国家级自然保护区环境因子}

在采集硅藻标本的同时共测定 9 个理化指标, 其结果如表 2 所示. 保护区地处北温带, 由于太阳辐射的变 
化, 水体温度表现出明显的季节差异性, 春、夏、秋季整体平均气温为 $15.8^{\circ} \mathrm{C} ; \mathrm{pH}$ 值平均值变化范围在 7. 0 ～7.6之间, 整体来看研究区内的水体属于中性、微碱性的环境; 根据中国水质指标的营养分类标准以及 文献 [21-22], 当 TP 浓度指标在 $0.01 \sim 0.025 \mathrm{mg} / \mathrm{L}$ 范围内为贫一中营养状态, 在 $0.025 \sim 0.05 \mathrm{mg} / \mathrm{L}$ 范围内 为中富营养状态, 在 $0.05 \sim 0.1 \mathrm{mg} / \mathrm{L}$ 范围内为中富营养状态, 在 $0.1 \sim 1.0 \mathrm{mg} / \mathrm{L}$ 范围内为富营养状态; 当 $\mathrm{TN}$ 浓度指标为 $0.2 \sim 0.5 \mathrm{mg} / \mathrm{L}$ 范围内为贫-中营养状态, 在 $0.5 \sim 1.5 \mathrm{mg} / \mathrm{L}$ 范围内为轻 - 中富营养状态, 在 $2.0 \mathrm{mg} / \mathrm{L}$ 以上为富营养状态, 综合 TN、TP 浓度表明, 本研究区大部分处于中营养状态. 化学需氧量 ( COD) 作 为有机物相对含量的指标之一, 数值越大, 说明水体受有机物污染越严重, 采样点 $\mathrm{V}$ 的 $\mathrm{COD}_{\mathrm{Cr}} 、 \mathrm{COD}_{\mathrm{Mn}}$ 值都高 于其他采样点,说明该水域中的有机物质丰富,有机物的污染相对较大;6 个采样点中 $\mathrm{BOD}_{5}$ 的变化不显著, 采样点 III 最高, 达到 $9.8 \mathrm{mg} / \mathrm{L}$, 其水中有机污染物可能较多, 导致 $\mathrm{BOD}_{5}$ 较高、DO 较低.

表 2 扎龙国家级自然保护区主要水质理化指标

Tab. 2 Main physical and chemical indexes of water quality in the Zhalong National Nature Reserve

\begin{tabular}{ccccccc}
\hline \multirow{2}{*}{ 理化指标 } & \multicolumn{7}{c}{ 采样点 } \\
\cline { 2 - 7 } & $\mathrm{I}$ & $\mathrm{II}$ & $\mathrm{III}$ & $\mathrm{I}$ & $\mathrm{V}$ & $\mathrm{VI}$ \\
\hline $\mathrm{WT} /{ }^{\circ} \mathrm{C}$ & 15.3 & 15.6 & 16.7 & 17 & 11 & 19 \\
$\mathrm{Cond} /(\mu \mathrm{S} / \mathrm{cm})$ & 451 & 477 & 309 & 290 & 311 & 321 \\
$\mathrm{COD}_{\mathrm{Cr}} /(\mathrm{mg} / \mathrm{L})$ & 28.3 & 28.1 & 29.9 & 27.0 & 32.5 & 32.0 \\
$\mathrm{COD}_{\mathrm{Mn}} /(\mathrm{mg} / \mathrm{L})$ & 9.44 & 7.68 & 10.28 & 9.76 & 11.54 & 10.17 \\
$\mathrm{BOD}_{5} /(\mathrm{mg} / \mathrm{L})$ & 8.2 & 8.0 & 9.8 & 7.7 & 7.2 & 9.5 \\
$\mathrm{DO} /(\mathrm{mg} / \mathrm{L})$ & 5.4 & 5.6 & 5.0 & 5.4 & 5.9 & 6.4 \\
$\mathrm{TN} /(\mathrm{mg} / \mathrm{L})$ & 0.99 & 1.10 & 0.87 & 1.00 & 1.08 & 0.90 \\
$\mathrm{TP} /(\mathrm{mg} / \mathrm{L})$ & 0.030 & 0.042 & 0.031 & 0.050 & 0.038 & 0.025 \\
$\mathrm{pH}$ 值 & 7.4 & 7.6 & 7.5 & 7.2 & 7.3 & 7.0 \\
\hline
\end{tabular}

\section{3 扎龙国家级自然保护区硅藻植物群落聚类分析及丰度变化}

对 6 个采样点不同季节的硅藻植物原始丰度数据处理后 (对环境指示较小的硅藻种类已经删除) 进行 平方根转换后, 构建 Bray-Curtis 相似性矩阵, 在此基础上采用组间平均聚类法进行分层次聚类分析. 聚类图 与不同季节各采样点硅藻植物群落组成的丰度图相结合, 聚类分析结果显示 (图 2), 将 34 个硅藻植物在相 似度水平上分成 5 个组 ( A1 A5) : A1 组由 13 个丰度较高的种类组成; $\mathrm{A} 2$ 组由 8 个硅藻种类组成 (相似度 为 50\%), 均为适应生态环境较宽的普生种类, 在春季各采样点的丰度较低, 而夏、秋季的丰度优于夏季; A3 组由 4 个种类组成 (相似度为 $43 \%$ ), 丰度不高, 但均在春季的采样点 I 大量出现; A4 组由 5 种硅藻组成 (相 似度为 $54 \%$; ; 5 由 4 个硅藻种类组成, 它们在春、秋两季丰度均较低.

\section{3 讨论与结论}

硅藻是一种光自养性藻类, 是水体里初级生产力的一种重要组成部分. 许多属种对某些水环境指标 ( 如 $\mathrm{pH}$ 值、盐度、温度、营养盐等) 都有特定的最佳值及忍耐值, 能很好地指示水环境的变化 ${ }^{[23]}$. 扎龙湿地地处中 纬度地带, 属于北温带大陆性季风气候, 夏季和秋季温差大, 水温的季节性变化明显, 秋季明显低于春、夏季 (变化范围为 $8.3 \sim 23.5^{\circ} \mathrm{C}$ ) ; 春、夏季的 $\mathrm{pH}$ 值总体呈中性至弱酸性, 秋季各采样点均呈弱碱性 (变化范围为 $6.70 \sim 8.26)$; 各采样点的电导率差别均较大 $(261 \sim 631 \mu \mathrm{S} / \mathrm{cm})$, 同一采样点不同季节的变化也较明显 (表 2). 扎龙国家级自然保护区内盐碱地面积约占保护区面积的 $4 \%{ }^{[24]}$, 其水生态系统和地理环境使硅藻植物 种类组成、数量、多样性等都具有其独特性, 从硅藻的种类组成和优势种分布特点来看, 硅藻植物主要以淡水 至半咸水、喜弱碱的种类为主, 如侧生窗纹藻、肘状脆杆藻弓形变种和弯棒杆藻等. 在 1989-2006 年期间, 该保 护区草地和沼泽地被大面积开垦为耕地, 特别是保护区的边缘地区, 导致保护区沼泽地面积减少; 由于水资源 不足, 也使得大量沼泽地转变为盐碱地 ${ }^{[13-14]}$, 作为优势种出现的许多硅藻种类都对环境特征有着非常明显的 指示响应. 8 个优势种类中, 弯棒杆藻、隐头舟形藻、明晰双肋藻在 3 个季节的大部分采样点中均有发现, 这 3 


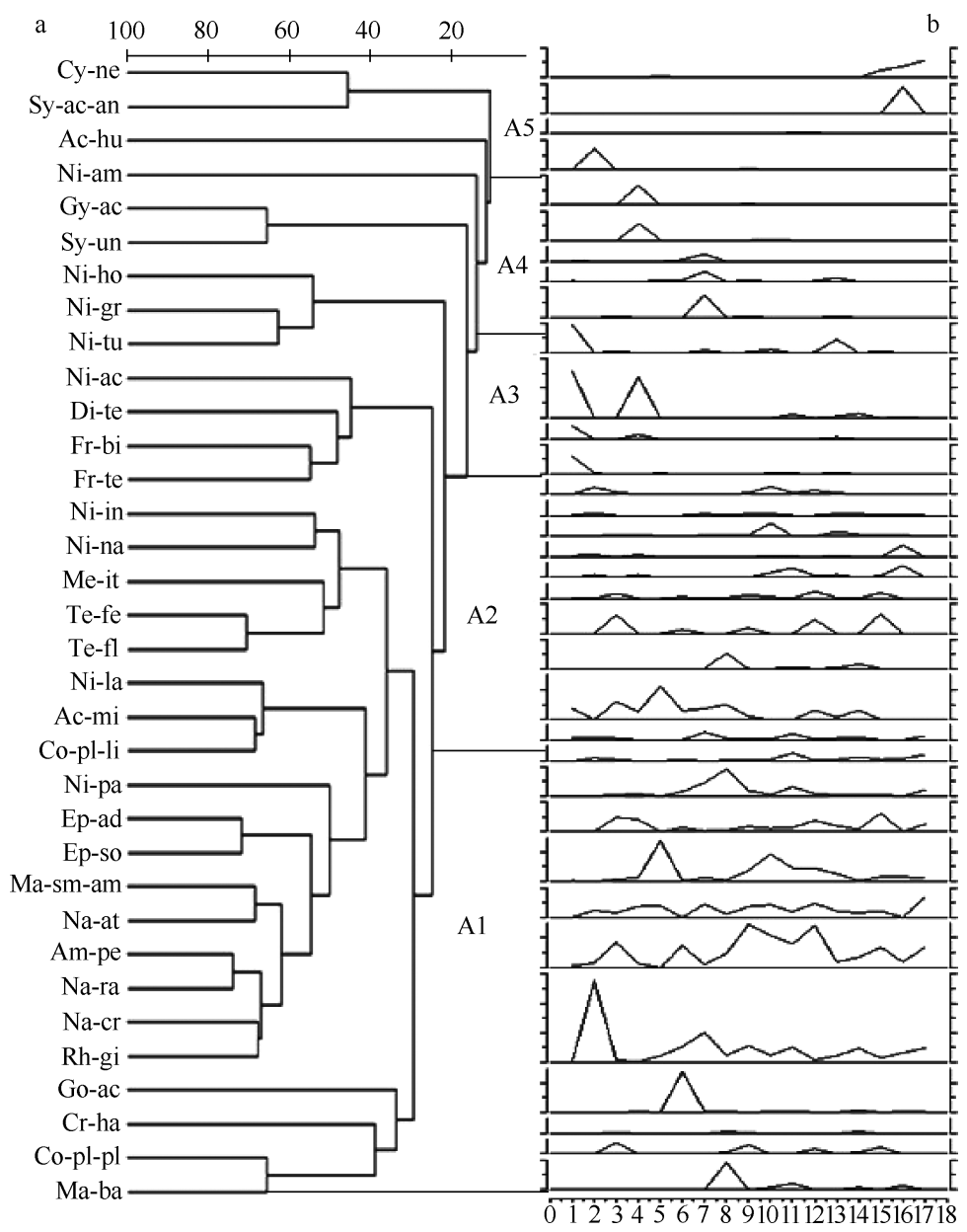

图 2 硅藻种群聚类图 (a) 及硅藻植物丰度 (b)

Fig. 2 Dendrogram based on the cluster analysis of the diatom communities(a) and the diatom richness(b)

种藻均属于广布种, 在北方地区水域经常能够发现, 如弯棒杆藻为典型的嗜碱种, 喜生活在寡盐水域, 已有研 究成果证实该种对水体的盐度和酸碱度能够起到明显的指示作用; 而隐头舟形藻生境范围较广, 喜欢微盐、适 碱的水体, 在富营养化的水体中也有存在 ${ }^{[4]}$. 由于该保护区的研究区域内出现大量的喜寡盐、微咸水、半咸水 及喜弱碱甚至一些嗜碱的种类, 说明扎龙国家级自然保护区的部分水域均受到土地盐碱化的影响.

水温通常是决定水生生物生长、发育和繁殖的重要因素之一. 硅藻能够适应多变的环境条件, 容易成为 水体主要种类, 并对环境有很好的指示作用, 具有较明显的响应特征 ${ }^{[8]}$. 扎龙自然保护区处于典型的北温带 季风气候区, 水温季节变化明显, 呈春季低, 夏季逐渐升高到最大值, 秋季降低, 冬季出现最低值. 相对冬季 和春季, 夏、秋两季水温升高, 光照充足, 营养盐丰富, 适合藻类植物生长, 容易成为水体主要种类. 采集区域 内春季以纤细等片藻、放射舟形藻、线毛平板藻等为组合特征, 这些种类的出现表明水质良好, 环境受人为 因素影响较小; 夏季水温升高, 一些冷水种减少, 出现的硅藻种类个体较大, 同时随着 TP 浓度的升高, 水体 中曾出现的一些寡污带指示种如纤细等片藻数量明显减少, 而弯棒杆藻成为该季节的优势种, 明晰双肋藻 和扁圆卵形藻多孔变种 (Cocconeis placentula var. euglypta) 也较为常见. 相对于春、夏季, 秋季的富营养情况 较为严重, 如在秋季大量出现窄异极藻、 $\alpha$-中污带指示种谷皮菱形藻, 以及耐有机污染的中污带指示种秋季 隐头舟形藻等占绝对优势, 这些优势种的出现进一步说明秋季水体富营养情况较其他两个季节严重. 秋季 水质下降可能是由于秋季雨水少, 水流速度缓慢, 造成水体内营养盐浓度的升高. 本研究在保护区内虽然也 
发现一些寡污带和中污带的指示种, 如极细微曲壳藻、辐头舟形藻等, 但种类数不多. 李晶等 ${ }^{[25]}$ 在 2009 年扎 龙国家级自然保护区夏、秋两季的调查中发现, 硅藻优势种类多以华丽星杆藻 (Asterionalla formosa) 、梅尼小 环藻和颗粒直链藻 (Melosira granulate) 为主 (表 3), 其中, 梅尼小环藻、颗粒直链藻是典型的中型污染指示种 群, 作为优势种群出现, 表明当时水域有一定程度的污染. 相比 2009 年的研究结果, 本次在扎龙湿地发现的 硅藻种类有所增加, 优势种类的时空分布上也有所不同; 而有些种类如华丽星杆藻等在本次研究中虽有发 现,但并未形成优势种群.

表 3 扎龙国家级自然保护区湿地浮游植物夏、秋两季优势种类

Tab. 3 Dominant species in the wetland of Zhalong National Nature Reserve in summer and autumn

\begin{tabular}{cccccc}
\hline 季节 & 优势种 & $\begin{array}{c}\text { 硅藻密度/ } \\
\left(\times 10^{4} \text { cells } / \mathrm{L}\right)\end{array}$ & 相对密度 $/ \%$ & 出现频率 & 优势度 \\
\hline 夏季 & 梅尼小环藻 & 3.14 & 10.43 & 0.70 & 0.07 \\
& 华丽星杆藻 & 3.89 & 12.94 & 0.48 & 0.06 \\
秋季 & 颗粒直链藻 & 1.36 & 4.97 & 0.52 & 0.03 \\
& 梅尼小环藻 & 2.34 & 8.56 & 0.57 & 0.05 \\
\hline
\end{tabular}

水体电导率的大小主要由溶解在水体的离子种类、浓度和水温等决定, 其中离子种类组成取决于流域 地质及土壤特征, 水越纯净, 电导率越低 (电阻率越高). 水中的电导率是测量水体的含盐成分、含离子成分、 含杂质成分等的重要指标, 也可反映湖泊富营养化发生的程度 ${ }^{[26]}$. 同时水体水质的电导率高低与营养盐浓 度有关, 随着营养盐减少, 电导率也逐渐降低 ${ }^{[27]}$. 在电导率较高的区域, 如春、秋季的采样点 I 、II 和夏季采 样点 II, 均出现大量的喜中 - 高电解质的指示种, 如虫形双眉藻 (Amphora pediculus)、梅尼小环藻、侧生窗纹 藻、谷皮菱形藻等. 扎龙国家级自然保护区 TP 和 TN 浓度秋季最高, 夏季次之, 春季最低, 且秋季 TP 浓度的 平均值 $(0.66 \mathrm{mg} / \mathrm{L})$ 达到春季的 3 倍, 而在 TN、TP 浓度较高的区域, 通常受到的有机污染相对较大. 扎龙国 家级自然保护区富营养程度表现为秋季最高, 春季最低, 秋季出现的硅藻有一部分为污染指示种, 如鼠形窗 纹藻、Craticula ambigua、隐头舟形藻、切断形桥弯藻等.

基于扎龙水域藻类植物的聚类分析, 在 A1 区出现丰度较高的种类组成多为喜弱碱、寡盐的种类, 如放 射舟形藻、弯棒杆藻、扁圆卵形藻原变种 (Cocconeis placentula var. placentula) 和波罗的海胸膈藻等, 这些种类 在采样点 I 的春、夏、秋季均有出现, 其余在该区域出现的大部分多为耐有机污染的指示种, 如管栖菱形藻、 侧生窗纹藻和鼠形窗纹藻等. 在采样点 II 的春、夏、秋 3 次采集中大量发现的谷皮菱形藻和隐头舟形藻等也 多为中污带的指示种. 扎龙保护区采样点 I 位于水流速度较缓的开放芦苇沼泽区域, 和其相邻的采样点 II 是一个小型的泡沼, 为鹤类养殖区附近的水域, 鹤类经常在此处活动, 致使营养化程度较高, 污染严重, 该采 样点电导率、TP 浓度、TN 浓度、 $\mathrm{COD}_{\mathrm{Cr}} 、 \mathrm{COD}_{\mathrm{Mn}}$ 均较高. 位于扎龙湖的采样点 $\mathrm{VI}$ 地处乌裕尔河和双阳河下游, 由于上游人类活动, 大量的工业和生活污水排放到水中, 此样点的溶解氧浓度较高, 在该区域的春、夏两季 中, 都发现了中污染的指示种, 如窄异极藻等, 并且富营养化的指示种类隐头舟形藻成为该样点的优势种.

硅藻植物群落在监测扎龙湿地水环境变化或富营养化过程中具有一定的指示作用, 随着环境理化特性 的改变, 硅藻群落组合会对环境变化做出及时响应和改变 ${ }^{[28]}$. 扎龙湿地硅藻植物种群的季节演替, 受理化及 生物因素, 如光照、营养物质以及生物竞争、摄食等的影响, 动态反映了水体各种生态因子的综合作用. 与前 期部分研究工作相比, 扎龙湿地近几年缺水严重, 人为活动频繁, 沼泽地面积减少, 湿地生物的栖息环境恶 化, 扎龙湿地普遍处于中营养状态, 个别区域出现富营养的状态. 赵宝林等 ${ }^{[29]}$ 的研究认为, 扎龙湿地的水体 污染情况为中污染, 只有少数几个样点为轻污染; 李晶等 ${ }^{[25]}$ 、王泽斌等 ${ }^{[30]}$ 的研究也显示, 虽然不同时间区域 内的硅藻植物群落优势种群不同, 但中度营养化指示种类的大量出现, 则显示有些水体已有一定程度的富 营养化. 于 2011 年春、夏、秋季对扎龙湿地硅藻植物群落组成及其分布特征的研究表明, 扎龙湿地研究区域 内的 6 个采样点, 水体存在轻微至中度污染, 个别水域出现富营养状态. 因此, 应采取相应的措施改善和保 护该地区的水域生态条件,防止其生态环境的进一步恶化. 


\section{4 参考文献}

[ 1 ] 韩博平,林旭钿,李 铁. 广东省大中型水库富营养化现状与防治对策研究. 北京: 科学出版社,2003.

[ 2 ] 贺 锋,吴振斌. 水生植物在污水处理和水质改善中的应用. 植物学报,2003,20:641-647.

[ 3 ] 刘俊咗, 张成君. 硅藻指数在水环境监测与评价中的应用. 环境监测管理与技术, 2009,21:12-16.

[ 4 ] Wu JT, Kow LT. Applicability of a generic index for diatom assemblages to monitor pollution in the tropical River Tsanwun, Taiwan. Journal of Applied Phycology,2002,14(1): 63-69.

[ 5 ] Wiśniewska M, Paczuska B. Dynamics of the phytoplankton community in mesotrophic Lake Borówno. Oceanological and Hydrobiological Studies, 2013, 42: 202-208.

[ 6 ] Gabyshev VA, Gabysheva OI. The structure of phytoplankton and physicochemical characteristics of the Kolyma River (Northeastern Siberia) in summer. Contemporary Problems of Ecology, 2013, 6: 268-275.

[ 7 ] Granado DC, Henry R. Phytoplankton community response to hydrological variations in oxbow lakes with different levels of connection to a tropical river. Hydrobiologia, 2014, 721 : 223-238.

[ 8 ] Crossetti LO, Stenger-Kovács C, Padisák J. Coherence of phytoplankton and attached diatom-based ecological status assessment in Lake Balaton. Hydrobiologia, 2013, 716: 87-101.

[ 9 ] 高亚辉, 虞秋波, 齐雨藻等. 长江口附近海域春季浮游硅藻的种类组成和生态分布. 应用生态学报, 2003, 14: 1044-1048.

[10］董旭辉,羊向东,王 荣. 长江中下游地区湖泊富营养化的硅藻指示性属种. 中国环境科学, 2006,26:570-574.

[11] Fan YW, Li J, Men XY et al. Preliminary description of the diatom community and its relationship with water physicochemical variables in Qixinghe wetland. Chinese Journal of Oceanology and Limnology, 2012, 30(3) : 379-387.

[12] 肖 方. 扎龙国家级自然保护区考察报告. 科技潮,2005,8:48-50.

[13］殷志强,秦小光,刘嘉麒等. 扎龙湿地的形成背景及其生态环境意义. 地理科学进展, 2006,25:32-40.

[14] 周利军,张雪萍. 扎龙国家级自然保护区景观格局变化研究. 湿地科学, 2010,8:74-78.

[15] 金相灿,屠清瑛. 湖泊富营养化调查规范:第 2 版. 北京:中国环境科学出版社, 1990:239-244.

［16］沈锡芬, 章宗涉,龚循矩等. 微型生物监测新技术. 北京: 中国建筑工业出版社, 1990.

[17] Krammer K, Lange-Bertalot H. Bacillariophyceae 1. Teil: Naviculaceae. Brelin: Spektrum Akademischer Verlag Heidelberg, 1997.

[18 ] Krammer K, Lange-Bertalot H. Bacillariophyceae 2. Teil: Bacillariophyceae, Epithemiaceae, Surirellaceae. Berlin: Spektrum Akademischer Verlag Heidelberg, 1997.

[19] Krammer K, Lange-Bertalot H. Bacillariophyceae 3. Teil: Centrales, Fragilariaceae, Eunotiaceae. Berlin: Spektrum Akademischer Verlag Heidelberg, 1997.

[20] Krammer K, Lange-Bertalot H. Bacillariophyceae 4. Teil: Achnanthaceae, Kritische Ergänzunge zu Achnanthes s. l. , Navicula s. str., Gomphonema Gesamtliteraturverzeichnis Teil 1-4. Berlin: Spektrum Akademischer Verlag Heidelberg, 1997.

[21] 金相灿,刘树坤,章宗涉等. 中国湖泊环境. 北京:海洋出版社, 1995.

[22]夏婷婷, 尚广萍. 基于地表水环境质量标准的富营养化评价方法. 皖西学院学报,2010,26(5):98-101.

[23] Bradshaw EG, Anderson NJ, Jensen JP et al. Phosphorus dynamics in danish lakes and the implications for diatom ecology and palaeoecology. Freshwater Biology, 2002, 47: 1963-1975.

[24] 王钰祺. 扎龙自然保护区湿地资源评价与水环境质量分析 [学位论文]. 哈尔滨:东北林业大学,2009.

[25] 李 晶,祁佩时,马 云等. 扎龙湿地夏秋季浮游植物群落结构. 东北林业大学学报, 2012, 40:86-90.

[26] 刘建康. 东湖生态学研究 (一). 北京:科学出版社, 1990 .

[27] 胡胜华, 高云霓, 张世羊等. 武汉月湖水体营养物质的分布与硅藻的生态指示. 生态环境学报, 2009,18:856-864.

[28 ] Philibert A, Gell P, Newall P et al. Development of diatom-based tools for assessing stream water quality in south-eastern Australia: assessment of environmental transfer functions. Hydrobiologia, 2006,572: 103-114.

[29] 赵宝林, 刘茂奇, 刘曼红等. 扎龙湿地自然保护区大型底栖动物群落特征与水质分析. 黑龙江水产, 2012, (4): 33-38.

[30］王泽斌,马 云, 李 晶. 扎龙湿地浮游植物群落结构及多样性研究. 环境科学与管理, 2011,36(5):14. 